\title{
BÓG WIECZNEGO POWROTU TEGO SAMEGO W FILOZOFII
} FRYDERYKA NIETZSCHEGO

DOI: http://dx.doi.org/10.12775/TiCz.2016.033

Mógłbym wierzyć tylko w Boga, który by umial tańczyćt*.

\section{l. WSTĘP}

Niniejsza praca jest próbą interpretacji poglądów jednego z najbardziej kontrowersyjnych filozofów wypowiadających się na temat Boga. Fryderyk Nietzsche, który jest bohaterem tej pracy, był głosicielem idei „śmierci Boga”, wrogiem religii chrześcijańskiej oraz systemów filozoficznych i politycznych. Trzeba jednocześnie zaznaczyć, że ujęcie Nietzschego tylko jako krytyka i burzyciela jest błędem. Wielość perspektyw, jakie mo-

* Paweł Pałasiński: magister filozofii, doktorant na Uniwersytecie Papieskim Jana Pawła II w Krakowie. Zainteresowania naukowe: filozofia egzystencjalna, filozofia poznania (pawel.palasinski@gmail.com).

** F. Nietzsche, Tak mówił Zaratustra. Książka dla wszystkich i dla nikogo, tłum. G. Sowiński, Kraków 2005, s. 41. 
żemy znaleźć w filozofii autora Tak mówił Zaratustra, skłania do poszukiwania różnych dróg interpretacji. Owa wielość przekracza uproszczenia i pozwala odkryć niewyeksponowane dotąd wątki rozważań Nietzschego.

W niniejszej pracy nasze zainteresowanie skupi się na problemie: czy w ramach filozofii Nietzscheańskiej możliwe jest istnienie Boga? Problem ten często jest pomijany, gdyż negatywne stanowisko bazylejskiego filozofa względem religii chrześcijańskiej niejako samo narzuca odpowiedź. Jednak, jak to bywa w przypadku wielu filozofów, rozwiązanie tego problemu nie jest takie proste, jak się początkowo wydaje.

\section{ll. DROGA LWA}

Nietzsche, opisując w Tak mówił Zaratustra trzy przemiany ducha ${ }^{1}$, przedstawił pewien schemat, który posłuży nam za ilustrację do klasyfikacji jego rozważań dotyczących Boga. Trzy przemiany ducha to trzy następujące po sobie etapy rozwoju myślenia człowieka o świecie oraz o nim samym. Każdy z etapów może również symbolizować rozwój ludzkiego rozumienia Boga, czyli swoistą drogę do Jego poznania.

Pierwszy etap przemian ducha przedstawiony przez Nietzschego (metaforycznie opisany jako przemiana $\mathrm{w}$ wielbłąda) to przyswojenie sobie powszechnie dostępnych prawd dotyczących świata - w tym też powszechnie rozumianej moralności. Drugi etap (opisany jako przemiana $\mathrm{z}$ wielbłąda $\mathrm{w}$ lwa) to negacja owych prawd poprzez zastosowanie odpowiedniego kryterium. Negacja ta jest konieczna, by osiągnąć etap trzeci, czyli stan, w którym nastąpi wyzwolenie od tych prawd. Stan ten to trzecia przemiana ducha (opisana jako przeistoczenie się lwa w dziecko), którego istotą jest afirmacja rzeczywistości w całej jej zmiennej różnorodności. Afirmacja ta nie jest obciążona żadnymi sankcjami, które mogłyby służyć człowiekowi do jej podporządkowania, czyli wytworzenia jakiejś niezmiennej prawdy o niej.

Pokrótce omówione wyżej trzy przemiany ducha możemy zastosować do klasyfikacji wypowiedzi Nietzschego na temat Boga. W tym wypadku otrzymujemy trzy grupy takich wypowiedzi. Pierwsza obejmować

1 Por. tamże, s. 26-27. 
będzie opis przyswojonych przez bazylejskiego filozofa koncepcji Boga. Druga grupa zawierać będzie negacje wyżej wspomnianych koncepcji, natomiast trzecia - nas najbardziej interesująca - dotyczyć będzie wypowiedzi wskazujących na obraz Boga, który jest zgodny z idami filozofii nietzscheańskiej. Oczywiście wypowiedzi z tej ostatniej grupy są u Nietzschego niezwykle rzadkie i często - jak się to okaże - dosyć niejasne. $\mathrm{Z}$ tych względów praca ta jest interpretacją, a nie próbą przedstawienia poglądów autora Ecce Homo na temat Boga.

Etap sprzeciwu wobec religii i co za tym idzie - religijnego rozumienia Boga obejmuje wszystkie rozważania mające na celu ukazanie, że to, jak jest i był pojmowany Bóg, nie może być w żaden sposób prawdziwe czy nawet pożyteczne. Nietzsche przedstawia różne sposoby, za pomocą których miało wykształcić się u ludzi pojęcie Boga². Sposoby te są przez filozofa potępiane i odrzucane. Pomimo iż ta część wywodów Nietzschego jest ciekawa i obejmuje wiele różnych perspektyw, to jest ona tylko negacją. To, co wydaje się rzeczywiście interesujące (bo mało eksponowane przez komentatorów), to problem: czy Nietzsche doszedł do jakiejkolwiek pozytywnej koncepcji Boga, czy też zamknął się całkowicie w ciągłej krytyce innych koncepcji? Innymi słowy, posługując się omówionym wyżej schematem z Tak mówił Zaratustra, możemy zapytać: czy Nietzsche przekroczył poziom negacji i odnalazł afirmatywną przez siebie koncepcje Boga?

\section{BÓG ŚWIATA PRAWDZIWEGO}

Postawiony powyżej problem nie jest bezzasadny, ponieważ Nietzsche w Woli mocy pisze o swojej filozofii:

(...) tutaj dąży się do osiągnięcia przeciwieństwa panteizmu: albowiem „wszystko doskonałe, boskie, wieczne” zmusza również do wiary w „powrót wieczny". Pytanie: czy przez moralność stało się także niemożliwym to panteistyczne stanowisko przytakujące? W rzeczy samej tylko Bóg

2 Przykładowo, Nietzsche pisze w $Z$ genealogii moralności, że Bóg mógł wyłonić się z idealizacji przodków i poczucia „długu” wobec nich. Por. F Nietzsche, $Z$ genealogii moralności. Pisma polemiczne, tłum. L. Staff, Kraków 2003, s. 66-67. 
moralny został przezwyciężony. Czyż ma to jaki sens przedstawiać sobie jakiegoś Boga „poza dobrem i złem?”. Czyżby był możliwy panteizm $\mathrm{w}$ tym sensie? Czyż usuniemy z procesu wyobrażenie zamiaru i mimo to przytakniemy procesowi? - Byłoby to wtedy, gdyby coś w obrębie tego procesu było osiągane w każdym tegoż momencie - i zawsze to samo ${ }^{3}$.

Powyższa wypowiedź autora Woli mocy sygnalizuje, że Nietzsche dopuszczał możliwość istnienia Boga i sytuuje nasz problem wokół pytania: czy jest możliwy Bóg „poza dobrem i złem”? To pytanie rodzi następne: czy jest w ogóle taka potrzeba? Zdaje się, że tak, ponieważ boskość zostaje tutaj związana z koncepcją wiecznego powrotu. Koncepcją, która jest jedną z podstawowych idei (obok nihilizmu, stawania się i woli mocy) używanych przez Nietzschego do opisu świata. Jak pisze filozof, „tylko Bóg moralny został przezwyciężony", zatem pytanie właściwe brzmi: dlaczego Nietzschego interesuje Bóg immoralny?

Nietzsche krytykuje ujęcie Boga, jako podstawy dla naszej moralności głównie dlatego, że taka teza automatycznie generuje podział na świat boski, idealny, wieczny (w terminologii Nietzschego nazywanym „światem prawdziwym”) oraz świat ludzki, ułomny i przemijający (ten z kolei nazywanym „światem pozornym”). Autor Zmierzchu bożyszcz znosi ten dualistyczny podział, poprzez negację świata idealnego („świata prawdziwego”) i stwierdza: „pozbyliśmy się świata prawdziwego: jakiż świat pozostał? Może pozorny? (...) Ależ nie! Wraz ze światem prawdziwym pozbyliśmy się również pozornego!"4. Zatem gdy znika jedno z pary przeciwieństw, nie ma powodu by to, co pozostało, czyli drugie z pary przeciwieństw, wartościować tak samo, jak gdyby istniało to, co jest jego przeciwieństwem. Mówiąc wprost, dla Nietzschego świat, w którym żyjemy, jest jedynym światem i jako taki nie posiada żadnego przeciwieństwa. Brak przeciwieństwa powoduje, że możliwość porównania zostaje usunięta, a wraz nią możliwość wartościowania świata. Przyjmując powyższe stwierdzenie dotyczące świata i przenosząc ową logikę na rozważania o Bogu, możemy powiedzieć, że jeżeli nie ma Boga pozaświatowego - dla Nietzschego Boga moralności - to pozostał tylko Bóg w pewien sposób

3 Tenże, Wola mocy, tłum. K. Drzewiecki, S. Frycz, Kraków 2009, s. 21.

${ }_{4}$ Tenże, Zmierzch bożyszcz, czyli jak filozofuje się młotem, tłum. P. Pieniążek, Kraków 2005, s. 26. 
immanentny, zawsze obecny w świecie, zawsze żywy i działający. Jednocześnie autor Poza dobrem i złem pisze o "całkowitym przeciwieństwie panteizmu”, co może budzić pewne wątpliwości, ponieważ, jak się zdaje, owym przeciwieństwem panteizmu jest właśnie całkowicie transcendentny względem świata Bóg moralności. Jednak ów Bóg nie jest transcendentny, ponieważ po pierwsze: nie jest Bogiem moralności, więc nie generuje podziału na dwa światy, po drugie: nie może być transcendentny, ponieważ Nietzsche a priori odrzuca takie ujęcie Boga.

Bazylejski filozof pisze w Antychrześcijaninie:

Gdy wynaleziono pojęcie «natura» jako przeciwieństwo pojęcia «Bóg», słowo «naturalny» musiało oznaczać tyle, co «zasługujący na odrzucenie» korzenie całego fikcyjnego świata stanowi nienawiść do naturalności (- rzeczywistości - ), jest on wyrazem głębokiego niezadowolenia z rzeczywistości... ${ }^{5}$

Przytoczony cytat mówi wyraźnie, że według Nietzschego na początku kształtowania się rozumienia świata ludzie nie posiadali rozróżnienia na dwa światy. Rozumienie świata jest tutaj związane $\mathrm{z}$ rozumieniem koncepcji Boga. Dodatkowo w zacytowanym powyżej fragmencie poruszony zostaje wspomniany już wcześniej proces, w którym ludzie dokonali podziału na dwie rzeczywistości. W tym miejscu naszych rozważań musimy pokrótce zapoznać się z tą koncepcją bazylejskiego filozofa, ponieważ rozumienie Boga jest nierozerwalnie związane $\mathrm{z}$ rozumieniem świata w filozofii nietzscheańskiej. Odsłonięcie obrazu tej rzeczywistości, którą autor Wiedzy radosnej uważał za prawdziwą, pomoże nam zrozumieć warunki, w których możliwa staje się dla niego koncepcja Boga.

Argumentacja Nietzschego opisująca podział świata na dwie światy jest zasadniczo prosta. Na początku ludzie nie znali i nie myśleli nic poza światem. Świat nie posiadał swojego przeciwieństwa - był wszystkim. Bóg siłą rzeczy musiał być wtedy rozumiany jako obecny świecie, był więc niejako „naturalny”. Dopiero późniejsze dzieje rozwoju ludzkości doprowadziły do tego, że rozumienie pojęcia Bóg wskazywało na jego transcendencje względem świata. Można powiedzieć, że proces ten do-

5 F. Nietzsche, Antychrześcijanin. Przekleństwo chrześcijaństwa, tłum. G. Sowiński, Kraków 1999, s. 48. 
prowadził do niejakiego wyparowania w myśleniu ludzi Boga ze świata ich faktycznej egzystencji. Wydaje się, że Nietzsche w swojej koncepcji podziału na świat prawdziwy i fałszywy akcentuje przepaść, jaka zrodziła się pomiędzy idealnym i wiecznym Bogiem a śmiertelnym i niedoskonałym człowiekiem. Przyczynę tego rozłamu upatruje filozof w rozdźwięku pomiędzy ludzkim dążeniem do doczesnego szczęścia a światem, który temu dążeniu staje na drodze. Transcendentny Bóg nie oznacza wg Nietzschego nic ponadto, że człowiek jest nieszczęśliwy i szuka drogi ucieczki od świata, który jest powodem jego nieszczęścia. Dodatkowo autor Antychrześcijanina pisze: „Cierpieć zaś przez rzeczywistość to tyle, co być «unieszczęśliwioną» rzeczywistością...”.

Zatem argumentacja Nietzschego przebiega w następujący sposób. Rzeczywistość nie posiada żadnej wartości, dlatego gdy próbujemy doszukiwać się przyczyny swojego niezadowolenia z niej, musimy ją porównać z czymś innym, stosując przy tym jakieś kryterium oceny. Człowiek posiada różnorodne nadzieje i oczekiwania, których wypełnienie się wcale nie musi mieć miejsca. W sytuacji, w której człowieka spotyka zawód następuje rozdźwięk pomiędzy tym, czego się chciało i oczekiwało, a stanem faktycznym. Nietzsche przekonuje, że w takiej sytuacji tworzy się w myśleniu człowieka obraz dwóch światów. Jednego, który nie spełnia jego oczekiwań, oraz drugiego, w którym oczekiwania te mogłyby być spełnione. Zdaniem bazylejskiego filozofa w taki właśnie sposób człowiek powołuje do życia drugi lepszy świat, który jest wyrazem ludzkich marzeń, a który jedyne, co naprawdę robi, to oczernia tą rzeczywistość, w której odbywa się ludzka egzystencja. Kryterium oceny wartości rzeczywistości jest tu zadowolenie człowieka ze skutków przedsięwziętych działań. Człowiek zatem oczekuje, że świat prawdziwy to taki, który będzie przewidywalny oraz zawsze przychylny jego poczynaniom. Jeżeli zaś świat nie dostosowuje się do jego wymagań, to człowiek niejako się na ten świat „obraża” i zwraca się w kierunku własnych wyobrażeń. Wyobrażenia te są tak mocno przez człowieka upragnione, że w jego umyśle zaczynają one funkcjonować jako coś, co wskazuje na realną rzeczywistość osiągalną po wydostaniu się z obecnej, ułomnej i sprawiającej zawód. Mówiąc wprost, życie w upragnionym świecie ma być dostępne człowiekowi dopiero po

6 Tamże. 
śmierci. Tak pokrótce powstaje uczucie urazy do świata, które Nietzsche nazywa uczuciem resentymentu.

Wracając do problemu Boga w filozofii autora Tak mówił Zaratustra. Bóg wyobrażonego świata prawdziwego to Bóg, od którego człowiek oczekuje, że będzie On dla niego dobry. Bóg ten musi być częścią świata wyobrażeń człowieka, ponieważ tylko tam Jego dobroć może być całkowicie urzeczywistniona. W ułomnym świecie codziennej ludzkiej egzystencji dobroć Boga jest często podawana w wątpliwość, natomiast w świecie prawdziwym, będącym wytworem ludzkich pragnień, dobroć Boga nie pozostawia żadnych wątpliwości. Bóg staje się zatem pociechą i nadzieją dla człowieka, że istnieje świat, w którym będzie się czuł dobrze $^{7}$. Bóg staje się zatem jednocześnie zwiastunem nadziei i symbolem ukazującym niedostatki rzeczywistości, w której człowiekowi przyszło żyć, co daje możliwość jej negatywnego wartościowania.

\section{BÓG IMMANENTNY}

Mając na uwadze powyższe uwagi, możemy stwierdzić, że bazylejski filozof postuluje takie ujęcie Boga, w którym byłby On potwierdzeniem rzeczywistości, w której żyjemy. Bóg możliwy w filozofii Nietzscheańskiej musiałby być w niej niejako zanurzony - być immanentny, a nie transcendentny. Immanencja Boga jest konieczna, gdyż inaczej generowałby On zgubny dla człowieka podział na świat prawdziwy i fałszywy. Natomiast niejasną kwestią pozostaje problem immoralności Boga.

Nietzsche na temat przypisywanej Bogu dobroci, a także mądrości, pisał:

Usuńmy najwyższą dobroć z pojęcia Boga: nie jest ona godna Boga. Usuńmy również najwyższą mądrość: jest ona próżnością filozofów, którzy zawinili tym szalonym pomysłem Boga jako potwora mądrości, powinien był jak najbardziej wyglądać podobnie do nich... Nie! Bóg najwyższą mocą - to wystarcza! Z niej wypływa wszystko, co wypływa - «świat»!

7 Por. tamże, s. 50-51.

8 Tenże, Wola mocy, s. 365. 
Z przytoczonej wypowiedzi jasno wynika, że zarówno mądrość, jak i dobroć przypisywana jest Bogu przez ludzi. Dobroć przyznawana jest Bogu ze względu na roszczeniowy charakter ludzkich wierzeń. Ludzie oczekują pocieszenia i pomocy od Boga, jak pisał Nietzsche: „(...) pojęcie Boga krok po kroku karłowacieje w symbol laski dla zmęczonych (...)"9. Dobry Bóg nie reprezentuje zdaniem autora Antychrześcijanina siły, a słabość, wspiera myślenie, które za swój cel uznaje oczekiwanie na pomoc zamiast agresywnego stawiania czoła przeciwnościom. Natomiast mądrość Boga jest jedynie podjętą przez filozofów próbą stworzenia Boga na swój obraz i podobieństwo. Nietzsche zatem odrzuca określenia Boga jako dobrego i mądrego i skłania się do określenia Go jak „najwyższej mocy”, z której wypływa świat. Określenie to jest niejasne i wymaga rozwinięcia i interpretacji. Możemy przypuszczać, że Nietzsche, pisząc o „najwyższej mocy”, ma na myśli jakąś formę woli mocy. Jeden z fragmentów Woli mocy zdaje się potwierdzać nasze przypuszczenie:

Jedyna możliwość zachowania sensu idei «Boga» byłaby ta: Bóg nie jest siłą poruszającą, lecz stanem maksymalnym, epoką, punktem w rozwoju woli mocy, z którego wyjaśnia się zarówno rozwój dalszy, jak i poprzedzający, i to, co do niego wiodło ${ }^{10}$.

Nietzsche pisze o Bogu jako o „stanie maksymalnym (...) w rozwoju woli mocy”, co potwierdza, że we wcześniejszym fragmencie, w którym filozof użył określenia „najwyższa moc”, miał on na myśli wolę mocy. Zacytowany wyżej fragment nie tylko rozwiązuje jedną z napotkanych niejasności, ale także wnosi wiele nowego do naszych rozważań, dlatego powinniśmy przyjrzeć się mu nieco dokładniej.

Autor Woli mocy w zacytowanym wyżej fragmencie wskazuje na istnienie „możliwości zachowania sensu idei «Boga»". Już w tym pierwszym zdaniu Nietzsche wskazuje na dwa ważne elementy jego myślenia o Bogu. Pierwszy dotyczy sformułowania „możliwość zachowania”, które zdaje się mówić, że autor hasła „Bóg umarł!” widzi możliwość dla uznania istnienia Boga. Wiemy, że Boga tego Nietzsche nie będzie określał jako dobrego czy mądrego oraz że nie będzie On generował podziału na świat

\footnotetext{
9 Tenże, Antychrześcijanin, s. 50.

10 Tenże, Wola mocy, s. 266.
} 
prawdziwy i fałszywy. Jednak te dane nie dają nam żadnego pozytywnego obrazu Boga. Innymi słowy, dalej nie jest jasne, co Nietzsche ma na myśli, pisząc "sens idei «Boga»". Przypomnijmy, że autor Antychrześcijaninia pisze o chrześcijańskim Bogu zazwyczaj w podobnym tonie, np. „Bóg formułą wszelkiego oczerniania «świata doczesnego», formułą wszelkiego kłamstwa o «zaświatach»! W Bogu ubóstwienie nicości, uświęcenie woli nicości!"11. Takie wypowiedzi zestawione z poprzednim fragmentem mówiącym o „możliwości zachowania sensu idei «Boga»” zdają się sprawiać wrażenie, iż Nietzsche pragnie wskazać właściwe rozumienie Boga, które nie zostało osiągnięte przez chrześcijaństwo. W tym momencie powraca pytanie: jak Nietzsche rozumie sens idei „Boga”?

$\mathrm{W}$ jednym $\mathrm{z}$ fragmentów Antychrześcijanina autor daje nam małą wskazówkę:

Drogą do Boga nie jest «pokuta», nie jest «modlitwa o przebaczenie»: jedynie ewangeliczna praktyka prowadzi do Boga, właśnie ona jest «Bogiem ${ }^{12}$.

Wydaje się, iż Nietzsche widzi „Boga” jako działanie ludzi zgodne z Ewangelią. Działanie opisane w Ewangelii, które pokazywał w swoim życiu Jezus, jest czymś więcej niż tylko działaniem ludzkim. Nietzsche wydaje się sugerować, iż to działanie jest Bogiem. Bóg tak pomyślany jest dynamiczny, jest działaniem, nie jest natomiast jasne, czy o tym Bogu mówił Nietzsche w Woli mocy ${ }^{13}$ oraz czy owo działanie jest wyrazem jakiejś sity istniejacej $w$ świecie, czy może jest ono przypisywane wyłącznie człowiekowi jako jego możliwość.

Nietzsche $w$ dalszej czesści zacytowanego wyżej fragmentu z Antychrześcijanina pisze:

Głęboki instynkt, który dyktuje, jak należy żyć, aby czuć się niebiańsko, aby czuć się «wiecznym», podczas gdy wszelka inna postawa nie pozwala czuć się niebiańsko: jedynie to jest psychologiczną realnością «zbawienia» ${ }^{14}$.

\footnotetext{
11 Tenże, Antychrześcijanin, s. 51.

12 Tamże, s. 70.

13 Por. tenże, Wola mocy, s. 365.

14 Tenże, Antychrześcijanin, s. 70.
} 
Z przytoczonego cytatu wynika, że pomimo tego, iż Nietzsche widział możliwość dla utrzymania idei „Boga” w swojej filozofii, to dla istnienia szeroko rozumianych „zaświatów” był bezwzględny - tych po prostu dla niego nie ma. Ten element w filozofii Nietzscheańskiej pozostaje niezmienny. Istotnym elementem dla naszych rozważań jest za to opisywana przez autora Antychrześcijanina możliwość zbawienia oderwana od koncepcji „zaświatów”. Możliwość ta jest dostępna dla człowieka podczas jego życia poprzez praktykę ewangeliczną. Co ciekawe, teza ta może być dla wielu czytelników zaskakująca, ponieważ mogło by się wydawać, że Nietzsche byłby ostatnim filozofem tak mocno akcentującym pozytywną wartość praktyki ewangelicznej.

Bóg jako działanie jest zakorzeniony w instynkcie człowieka do „niebiańskiego" czucia się. Przypuszczalnie słowo „niebiański” oznacza tu „szczęśliwy”. Jeżeli nasza intuicja jest prawidłowa, to rodzi ona pytanie: czym jest szczęście dla Nietzschego? Odpowiedź również odnajdujemy w Antychrześcijaninie, gdzie Nietzsche pisze: „Co jest szczęściem? - Poczucie, że moc rośnie, że opór zostaje przezwyciężony” ${ }^{15}$. Szczęściem jest zatem poczucie przyrostu mocy, a dokładniej woli mocy.

Bóg Nietzschego wydaje się być działaniem, które jest zbieżne ze wzrostem woli mocy. Jednak ta interpretacja nie pokrywa się z zacytowaną wyżej wypowiedzią Nietzschego z Woli mocy, gdzie bazylejski filozof pisze, że Bóg „nie jest siłą poruszającą, lecz stanem maksymalnym”. Bóg zatem jest momentem, w którym wola mocy osiąga swoją pełnię. Człowiek może doświadczyć przez praktykę ewangeliczną poczucia „wieczności”, „niebiańskości”, czyli pełni woli mocy. W człowieku zatem boskość odczuć można jedynie w takim działaniu, jakiego nauczał i jakie pokazywał Jezus, natomiast sam Bóg nie jest tym działaniem.

\section{BÓG WIECZNEGO POWROTU}

Bóg jest dla Nietzschego „stanem maksymalnym” w rozwoju woli mocy. Nietzsche wskazuje również w cytowanym wyżej fragmencie z Woli mocy, że tak rozumiany Bóg wyjaśnia cały przebieg wiecznego powrotu

15 Tamże, s. 38. 
tego samego. Wieczny powrót tego samego prowadzi do urzeczywistnienia się Boga jako maksimum woli mocy w świecie. Wszystko, co dzieje się podczas jednego obiegu wiecznego powrotu, prowadzić ma do tak rozumianego Boga, wszystko ma być przez ten fakt uzasadnione, jak sugeruje to Nietzsche. Wydaje się, że Bóg objawia się w swojej pełni w momencie kulminacyjnym każdego „obrotu” wiecznego powrotu tego samego.

Cechą charakterystyczną koncepcji wiecznego powrotu tego samego jest to, iż przybliża ona stający się świat do bytu ${ }^{16}$. Przybliżenie to polega na tym, że potwierdza ona wieczne stawanie się świata, przy jednoczesnym wprowadzeniu weń pewnego elementu stałości. Ponieważ wszystko się powtarza zawsze tak samo, to w ujęciu całego procesu jako czegoś jednego, pozostaje takie samo - niezmienne i wieczne. Wieczny ruch stawania się jest według Nietzschego sam w sobie doskonały ${ }^{17}$. Ruch ten jest kołowy, zatem świat nie posiada ani końca, ani początku, istnieje wiecznie $^{18}$. Zapytajmy jednak ponownie: jak możliwy jest w tym ciągle stającym się świecie Bóg? Jak pamiętamy, Nietzsche zadaje to samo pytanie i odpowiada: „Byłoby to wtedy, gdyby coś w obrębie tego procesu było osiągane w każdym tegoż momencie - i zawsze to samo"19. Tym czymś jest doskonałość, wieczność i boskość osiągana w każdej chwili tego procesu wiecznego krążenia.

W tym momencie naszych rozważań pojawia się pewien dysonans. Bóg, jak pamiętamy, ma być „stanem maksymalnym” woli mocy, czyli punktem kulminacyjnym obiegu w wiecznym powrocie tego samego. Jednak Nietzsche pisze o czymś, co byłoby osiągalne w każdym momencie obiegu. Mówiąc wprost: czy Bóg u Nietzschego jest kulminacją procesu, czy jest On może obecny w każdym momencie tego procesu?

W koncepcji wiecznego powrotu tego samego każda chwila jest wieczna i trwała, ponieważ ulega nieskończonym ilościom powtórzeń

16 Tenże, Wola mocy, s. 233.

17 Dodatkowo dla Nietzschego taki ruch jest też bezkonkurencyjny, ponieważ odrzuca on linearną wizję czasu. Autor Woli mocy pisze: „ "Poza czasem» do odrzucenia” co oznacza, że nie zgadza się on również na wizję świata poza czasem. Por. tamże, s. 316.

18 Por. tenże, Pisma pozostałe, tłum. B. Baran, Warszawa 2009, s. 422. Zdaje się, że Nietzsche nawiązuje tym poglądem do myśli Heraklita, który pisał „początek i koniec na koła obieganiu".

19 Tenże, Wola mocy, s. 21. 
w niezmienionej formie. Wydaje się, że każda chwila jest doskonała, ponieważ nie może być inna - ani lepsza, ani gorsza - ona jest zawsze dokładnie taka sama. Dwa wspomniane wyżej warunki zmuszają człowieka, według Nietzschego, do wiary w wieczny powrót tego samego. Wieczność i doskonałość wynikają, jak się zdaje, z samej natury wiecznego powrotu. Bez wiary w wieczny powrót chwila jest tylko ulotnym zbiegiem okoliczności, jest przemijająca, a jej doskonałość wątpliwa. Pozostaje zatem trzeci wymieniany przez bazylejskiego filozofa warunek - boskość.

Boskość, o której pisze Nietzsche, zdaje się oznaczać pewne uświęcenie całego procesu wiecznego powrotu jako czegoś, co nie jest przedmiotem naukowych rozważań i dowodzenia, a wiary człowieka. Każda chwila wiecznego powrotu jest wieczna, doskonała i boska dzięki temu, że cały proces ulega nieskończonej ilości powtórzeń. Sama istota procesu wpływa na elementy, z których się składa, czyli na wszystkie chwile jego w obrębie. Wydaje się, że tym, co pozostaje niezmienne w całym procesie wiecznego powrotu tego samego, jest jego natura, czyli wieczność, doskonałość i boskość.

Bazylejski filozof opiera swoją argumentacje za wiarą w wieczny powrót na subiektywnym odczuciu ludzi cech: boskości, wieczności i doskonałości. Nietzsche nie mówi, jak miałyby się uwidaczniać owe cechy. Ta nieokreśloność powoduje, że mogą być one przez ludzi różnie interpretowane, co skutkuje większą szansą na akceptację faktu, iż w świecie te cechy są obecne. Dalej przypadki, w których człowiekowi wydaje się, iż świat jest boski, wieczny i doskonały, wcale nie muszą prowadzić do wniosku, że świat jest taki przez cały czas. Mowa tutaj o subiektywnych odczuciach jednostki, o stanach emocjonalnych, które nie muszą się odnosić do obiektywnej rzeczywistości. Wydaje się, że Nietzsche jest niejako rozgrzeszony $\mathrm{z}$ tych błędów, ponieważ pisze on wprost, że chodzi o „wiarę” w wieczny powrót tego samego, a nie o wiedzę, iż ma on rzeczywiście miejsce. Realność podstawy tej wiary jest kwestią wyboru jednostki. Czy powinniśmy zatem uważać Nietzschego za niespełnionego twórcę nowej religii? ${ }^{20}$ Odpowiedź na to pytanie pozostawmy bez

${ }^{20}$ Jeden z komentatorów filozofii Nietzschego nazywa ją wprost” indywidualistyczną religią zastępczą". Por. I. Frenzel, Nietzsche, tłum. J. Dziubiński, Wrocław 1994, s. 120. 
odpowiedzi, ponieważ nie jest ona bezpośrednio związana $\mathrm{z}$ tematem niniejszej pracy.

Natura cyklicznego procesu stawania się, czyli jego boskość, wieczność i doskonałość, jest stała i niezmienna, ponieważ jest osiągana w każdym jego momencie. Jak pamiętamy, autor Woli mocy pisał, że Bóg byłby możliwy, „(...) gdyby coś w obrębie tego procesu było osiągane w każdym tegoż momencie - i zawsze to samo"21. Wydaje się, że w filozofii Nietzscheańskiej natura wiecznego powrotu to natura Boga, ponieważ tylko On może być boski. Człowiek jako istota skończona tylko ciągle przechodzi przez bramę chwili (bramę „Mgnienie”), staje się ciągle i nigdy się nie osiąga, a jedynie dobiega do swego kresu po to tylko, aby cykl ten mógł się powtórzyć2 ${ }^{22}$. Bóg osiąga się w każdej chwili jako doskonały i wieczny; mimo iż jego natura jest niezmienna, to nie przeczy On światu, ponieważ jest jego wewnętrznym dynamizmem. Nietzscheański Bóg jest zatem w świecie stającym się, lecz jest również jego elementem paradoksalnym - bo niezmiennie wiecznym i doskonałym. Nie trudno zauważyć, że tak rozumiany Bóg, który jest w każdej chwili inny, przez co nie może zobowiązywać moralnie ani nawet w ogóle być związany $\mathrm{z}$ jakąkolwiek moralnością.

Nie da się ukryć faktu, że Nietzschemu w jego filozofii chodziło o to, aby ludzie odbierali pozytywnie rzeczywistość, w której żyją. Temu celowi służyło chociażby omówione w niniejszej pracy zniesienie dualizmu świata prawdziwego i fałszywego. Jednak koncepcja Boga wyrosła z tej interpretacji wydaje się mało satysfakcjonująca. Przejdźmy zatem do drugiej możliwości interpretacyjnej, w której to Bóg nie jest stałym elementem procesu stawania się, lecz jest $\mathrm{w}$ nim stanem maksymalnym woli mocy.

\section{Vl. OCZEKIWANIE NA BOGA}

Jak pamiętamy, cechą charakterystyczną wiecznego powrotu tego samego jest to, że każdy obieg świata musi powtórzyć się niezliczoną ilość razy. Możemy zatem przypuszczać, że Bóg nie utrzymuje się w swo-

21 F. Nietzsche, Wola mocy, s. 21.

${ }^{22}$ Por. tenże, Tak mówił Zaratustra, s. 156-158. 
im istnieniu cały czas, jako punkt kulminacyjny w rozwoju woli mocy, tylko pojawia się raz w każdym obiegu wiecznego powrotu. Hipoteza ta przywodzi na myśl ideę zawartą w micie o greckim bogu Dionizosie. W micie tym Dionizos zostaje rozszarpany na kawałki przez tytanów, by później - jak opisuje to Nietzsche - zostać ponownie „złożonym” przez innego boga, Apolla ${ }^{23}$. Połączywszy historię zawartą w micie o Dionizosie $\mathrm{z}$ koncepcją wiecznego powrotu tego samego, otrzymujemy obraz Boga cyklicznie rodzącego się i umierającego.

Połączenie Dionizosa z koncepcją wiecznego powrotu wydaje się być uzasadnione, zważywszy na projektowane przez Nietzschego nazwy poszczególnych części nieukończonej nigdy książki Przewartościowanie wszystkich wartości. Czwartą część tej książki zamierzał nazwać Dionizos. Filozofia wiecznego powrotu ${ }^{24}$. W Woli mocy czytamy natomiast: „(...) pokrajany na części Dionizos jest obietnicą życia, wiecznie będzie rodzić się na nowo i powracać z rozbicia"25. Warto zaznaczyć, że filozof akcentuje nie dramatyczny moment rozpadu Dionizosa, lecz jego ciągłe powracanie, rodzenie się na nowo. Nasze przypuszczenia skłaniają nas do wniosku, iż historia świata w koncepcji wiecznego powrotu Nietzschego dąży do ponownych narodzin Dionizosa. Rozwój świata, czyli proces dopełniania się każdego obiegu w wiecznym powrocie tego samego, to rozwój woli mocy - jej umacnianie się mające na celu swoje maksimum, czyli Boga.

Co ciekawe, Nietzsche Dionizosowi przeciwstawia wiarę w „Ukrzyżowanego", przy czym zupełnie ignoruje fakt, że chrześcijanie również oczekują ponownego przyjścia Boga - Jezusa na koniec czasów. W tym punkcie, pomijając oczywiście kwestię tak nielubianych przez bazylejskiego filozofa „Zaświatów”, rozwój świata w chrześcijaństwie i w przedstawianej przez Nietzschego możliwej wierze w dionizyjskiego Boga jest bardzo podobny. Świat chrześcijan i świat wyłaniający się z filozofii autora Zmierzchu bożyszcz dąży do tego samego - do uobecnienia się Boga w jego pełnej sile na ziemi.

Wyżej opisane dość dalekie podobieństwo może sugerować, że Nietzsche nie przemyślał do końca swoich rozważań na temat chrześci-

\footnotetext{
${ }^{23}$ Por. tenże, Światopoglad dionizyjski, w: tenże, Pisma pozostałe, s. 51.

24 Tenże, Pisma pozostałe, s. 437.

25 Tenże, Wola mocy, s. 479.
} 
jańskiego Boga. Filozof z jednej strony wypowiada się niezwykle ciepło o praktyce ewangelicznej, którą pokazał Jezus, z drugiej zaś całkowicie odrzuca chrześcijańskiej ujęcie Boga jako nie dość, że fałszywe, to jeszcze szkodliwe. Można zadać pytanie: czy nie lepiej byłoby, gdyby Nietzsche próbował interpretować Pismo Święte - a poprzez to wpłynąć na kształt religii chrześcijańskiej - w duchu praktyki ewangelicznej, niż wskrzeszać dawno „umarłego” greckiego boga Dionizosa? Odpowiedź na to pytanie nie jest przedmiotem niniejszej pracy, lecz zasygnalizowany tu problem wydaje się interesujący.

\section{VIl. BÓG A WOLA MOCY}

Bóg dla autora Poza dobrem i złem może być momentem w obiegu wiecznego powrotu tego samego, gdy wola mocy osiąga swoje maksimum. Określenie to wydaje się niejasne, ponieważ pojęcie „wola mocy” nigdy nie zostało przez bazylejskiego filozofa zdefiniowane ${ }^{26}$. Zapytajmy wobec tego inaczej: jak przejawia się wola mocy? W Pismach pozostałych Nietzsche pisze: „Gdziekolwiek widziałem życie, znajdowałem wolę mocy; nawet w woli służącego znajdowałem wolę mocy"27. Filozof zadaje się twierdzić, że każde działanie istot żywych jest wyrazem jednej siły - woli mocy. Dalej Nietzsche pisze w Antychrześcijaninie:

Co jest dobre? - Wszystko, co zwiększa w człowieku poczucie mocy, wolę mocy, samą moc. Co jest liche? - Wszystko, co pochodzi ze słabości. Co jest szczęściem? - Poczucie, że moc rośnie, że opór zostaje przezwyciężony. Nie zadowolenie, lecz większa moc; nie pokój w ogóle, lecz wojna; nie cnota, lecz tężyzna (cnota w renesansowym stylu, virtù, cnota wolna moralizatorstwa $)^{28}$.

${ }^{26}$ T. Gómez uważa, że jest to spowodowane poglądami Nietzschego na temat języka. Por. T. Gómez, Człowiek i twórca Fryderyk Nietzsche, tłum. G. Ostrowski, Warszawa 2007, s. 163. Jednak w wypowiedziach bazylejskiego filozofa autor niniejszej pracy nie znalazł jednoznacznego poparcia dla tej tezy.

27 F. Nietzsche, Pisma pozostałe, s. 318.

28 Tenże, Antychrześcijanin, s. 38. 
W przytoczonym cytacie bazylejski filozof pisze o woli mocy w kontekście człowieka i jego działania. We wcześniej zacytowanym fragmencie z Pism pozostałych autor pisze ogólnie o tym, że wola mocy przysługuje wszystkiemu, co żyje. Nietzsche pisze zatem o woli mocy na różnych poziomach. Na poziomie metafizycznym wola mocy zdaje się stanowić arché filozofii nietzscheańskiej, z kolei na poziomie antropologicznym stanowi ona źródło motywacji niezbędnej człowiekowi do podjęcia działania. Poczucie szczęścia człowieka jest efektem ubocznym woli mocy.

Wzrost mocy człowieka może wpływać na jej przyrost w świecie. Jeżeli człowiek jest w stanie wpływać na przyrost woli mocy w świecie, to może on doprowadzić do jej stanu maksymalnego. Stanu, w którym, jak pamiętamy, ma urzeczywistnić się Bóg. Zatem moment maksymalnego rozwoju woli mocy wydaje się być momentem maksymalnego rozwoju człowieka, ponieważ tylko on spośród istot żywych może walczyć ze swoimi słabościami. Zwierzęta działają instynktownie, a człowiek potrafi racjonalnie zaplanować własny rozwój, wykraczając tym samym poza swój instynkt.

Moment maksymalnego rozwoju ludzkości budzi wiele wątpliwości. Załóżmy, że ludzkość osiąga moment swojego największego rozwoju i przy nim pozostaje, ponieważ więcej osiągnąć się nie da. Jednak taki stan rzeczy kłóci się z twierdzeniem Nietzschego o stawaniu się świata, które wyklucza osiągnięcie jakiegokolwiek stanu stałego w świecie. Wydaje się zatem, że moment osiągnięcia przez ludzkość swoich granic i urzeczywistnienia się Boga, jako że to On jest stanem maksymalnym woli mocy, musi prowadzić do katastrofy. Zmiana w momencie całkowitej pełni i doskonałości musi być siłą rzeczy zmianą na gorsze. Możemy zatem jedynie przypuszczać, iż zmiana taka może być stopniowa bądź skokowa i będzie się ona charakteryzowała spadkiem siły woli mocy w świecie.

Inną sposobem rozwiązania zagadki tego, co się dzieje po osiągnięciu stanu maksymalnego woli mocy, jest możliwość, iż po zdobyciu tego stanu obieg wiecznego powrotu się powtarza. Bóg pojawia się zatem tylko wtedy, gdy ludzkość osiągnie to, co jest możliwe dla ich własnego szczęścia. Pojawienie się Boga oznacza koniec obiegu i początek nowego takiego samego. W takim wypadku wyjaśniony zostałby sposób, w jaki następuje wieczny powrót. Ludzkość doskonali się, by osiągnąć kres swo- 
ich możliwości, co ma spowodować pojawienie się Boga, następnie proces doskonalenia się zostaje powtórzony.

Można zadać pytanie: dlaczego taki Bóg miałby być upragniony dla ludzi? Wydaje się, że wynikać to ma z natury tego, czym jest dla Nietzschego szczęście. Ludzie osiągają szczęście, gdy czują, że „opór zostaje przezwyciężony”. W momencie maksymalnym woli mocy nie ma już oporu, wszystko wydaje się już być przezwyciężone. Jedyną możliwością na przezwyciężanie oporu jest zatem powtórzyć drogę, którą ludzkość już raz przebyła. Wydaje się, że Bóg możliwy w filozofii Nietzscheańskiej to Bóg, który jest obietnicą zarówno rozwoju ludzkości, jak i obietnicą tego, że rozwój ten nigdy nie ustanie, że będzie on wiecznie powtarzany. Analogia z mitem o Syzyfie narzuca się sama, ponieważ nagrodą za trud jest tu jego powtórne doświadczenie.

\section{MISTYYCZNE DOŚWIADCZENIE NIETZSCHEGO}

Wizję wiecznego powrotu można nazwać doświadczeniem mistycznym, ponieważ nosi ona takie cechy. Cechy te to: 1. nietrwałość, 2. poczucie jedności, 3. silne przeświadczenie o rzeczywistości lub obiektywności doświadczenia polegające na przekonaniu, że jest ono prawdziwe i niezależne od podmiotu, 4. połączenie sprzeczności ${ }^{29}$. Wizja wiecznego powrotu tego samego posiada wszystkie wyżej wymienione cechy.

Wizja wiecznego powrotu wprowadza poczucie jedności, ponieważ poprzez ukazanie cykliczności świata prowadzi do ujęcia go w jeden proces. Dalej łączy sprzeczności, takie jak wieczność świata i jego spostrzegana przez człowieka zmienność. Nie można również zaprzeczyć, że Nietzsche miał silne przekonanie o prawdziwości swojej wizji w takim znaczeniu, że oddaje ona obiektywny charakter świata. Jeżeli zaś cho-

${ }^{29}$ Cechy doświadczenia mistycznego podane są na podstawie pracy J. Sieradzana pt. Czy Nietzsche był mistykiem chrześcijańskim. Sieradzan podaje pierwszą cechę - nietrwałość za W. Jamesem, następne zaś za R. M. Gimello. Por. J. Sieradzan, Czy Nietzsche był mistykiem chrześcijańskim, NOMOS 50 (2006). W pracy nie została podana ostatnia cecha, którą wyszczególnia Gimello - mówiąca o nadzwyczajnie silnym tonie uczuciowym, ponieważ w przypadku wypowiedzi Nietzschego, żadna nie wydaje się „nadzwyczajnie” nasycona uczuciami; większość jest podobnie - czyli silnie - nasycona. 
dzi o cechę nietrwałości, to trzeba zaznaczyć, że koncepcja wiecznego powrotu w postaci, jaką ją spisał Nietzsche, jest czymś wtórnym wobec doświadczenia, jakim była wizja wiecznego powrotu, którą przeżył w Sils-Maria w 1881 roku. Co wydaje się oczywiste, opis nie potrafi wzbudzić w człowieku tak niepodważalnego poczucia harmonii świata, jak samo przeżycie owej harmonii. Nietzsche opisuje swoje doświadczenia jako:

Pięć, sześć sekund, nie więcej i oto czujecie nagle obecność wiecznej harmonii. (...) Zda się wam, że jesteście w kontakcie z całą naturą i mówicie: «tak, to prawdziwe!» (...) Najbardziej nieznośna jest straszliwa określoność, z jaką się ono wyraża, i jaką ono napełnia ${ }^{30}$.

Przytoczona wypowiedź autora Tak mówił Zaratustra nie mówi wprost o jakimś określonym jego przeżyciu. Możemy jedynie się domyślać, czy rzeczywiście bazylejskiemu filozofowi chodzi tu o wizję wiecznego powrotu. Jednak wizja wiecznego powrotu pokazuje, że „stawanie się jest wielkim pierścieniem”, w którym „każda rzecz jest jednako warta, wieczna, konieczna" ${ }^{11}$, co wydaje się potwierdzać nasze przypuszczenie. W tym wypadku wizja wiecznego powrotu posiada cechę nietrwałości, co ostatecznie zdaje się potwierdzać tezę, iż była ona doświadczeniem mistycznym, którego dostąpił Nietzsche.

\section{ZAKOŃCZENIE}

Doświadczenie mistyczne wiecznego powrotu ujawniło jednak coś więcej niż tylko to, że świat posiada cykliczną naturę. Ujawniło ono również immanentnie tkwiący w nim element stały, który poprzez swoją niezmienność przekracza to, w czym się znajduje. Ten element, jakkolwiek Nietzsche nie mówi o tym wprost, możemy zinterpretować jako Boga, „który by umiał tańczyć”32, ponieważ będąc jednocześnie wiecznym i doskonałym, uczestniczy w procesie stawania się świata. Nie jest to Bóg religii, którego neguje Nietzsche - jest to Bóg, który wykracza poza mo-

\footnotetext{
30 F. Nietzsche, Pisma pozostałe, s. 403-404.

31 Por. tenże, Wola mocy, s. 165.

32 Por. tenże, Tak mówił Zaratustra, s. 41.
} 
ralność i ludzkie poznanie. Autor Tak mówił Zaratustra pozostawił nam materiał, z którego udało nam się wyinterpretować Boga poza dobrem i złem, który przejawiałby się w zmiennym świecie ludzkiej egzystencji. Boga, który wykluczałby możliwość podziału na świat doskonały i niezmienny oraz ułomny i zmienny, a poprzez to rodzący negacje świata, w którym żyje człowiek.

$\mathrm{Na}$ koniec warto zaznaczyć, że pomimo narzucającej się, wszechobecnej negacji wszystkich prawd w filozofii Nietzscheańskiej, niniejsza praca pisana była na wskroś w duchu tejże filozofii. Autor Wiedzy radosnej pisał: „(...) nie chcę znać żadnych spraw i zagadnień, które nie dopuszczają eksperymentu. Oto granica mojego «zmysłu prawdy»: bo tam waleczność straciła swe prawo" ${ }^{33}$. Praca ta była eksperymentem polegający na poszukiwaniu Boga możliwego - nieprzeczącego założeniom filozofii opartej na wizji świata jako cyklicznego stawania się. Interpretacyjnym eksperymentem, który w świetle przytoczonego cytatu znalazłby poparcie Nietzschego.

Streszczenie. Bóg wiecznego powrotu tego samego w filozofii Fryderyka Nietzschego. Fryderyk Nietzsche walczył w swoich książkach przeciwko chrześcijańskiemu Bogu, jednocześnie podczas tej walki mówił o swoim rozumieniu Boga, co prowadzi nas do pytania: jeżeli Bóg moralności, chrześcijański Bóg umarł dla Nietzschego, to czy oznacza to również, że sam Bóg dla niego umarł?

Niniejszy artykuł jest próbą odpowiedzi na powyższe, niełatwe pytanie. Wizja wiecznego powrotu tego samego daje możliwość umieszczenia koncepcji Boga wśród innych kluczowych idei Nietzschego, jak wola mocy czy nihilizm. Jedną z możliwości usytuowania Boga wśród innych idei filozofii nietzscheańskiej jest ukazanie, że Bóg żyje w każdym momencie wiecznego powrotu. Druga możliwość ukazuje Boga jako stan maksymalny nietzscheańskiej koncepcji wiecznego portu.

Niniejszy artykuł jest interpretacyjnym eksperymentem, ponieważ Nietzsche nigdy nie pisał wprost o swoim rozumieniu Boga, w którego mógłby wierzyć. Jednocześnie jest zastanawiające, iż Nietzsche poświęcił tak wiele miejsca w swojej filozofii Bogu oraz jak wiele możemy się dzięki temu dowiedzieć o jego wizji Boga.

Słowa kluczowe: Nietzsche; Bóg; wola mocy; nihilizm; wieczny powrót.

Abstract. The God of the Eternal Return in Friedrich Nietzsche's philosophy. Friedrich Nietzsche in his books fought against the christian God and during his fight

33 Tenże, Wiedza radosna, s. 61. 
he spoke about how he understands God. That leads us to the question: If the God of morality, the christian God died for Nietzsche, does that mean that God himself died for Nietzsche too?

This paper strives to show that the answer to this question is not simple. Nietzsche's phantasm of the Eternal Returning gives possibilities to place the concept of God among others fundamental ideas of Nietzsche's philosophy, like the will to power or nihilism. One of the possibilities described in this paper shows that God lives in every moment of the Eternal Return. The second possibility shows that God is the climax of the Nietzsche's idea of the Eternal Return.

This article is of course only an interpretative experiment because Nietzsche never wrote directly about the understanding of the God that he might believe in. However one might wonder why Nietzsche wrote so much about God in his books and how much we can find out about his understanding of God.

Keywords: Nietzsche; God; will to power; nihilism; the Eternal Return. 